\title{
Pituitary responsiveness to synthetic LH-RH and pituitary LH content at various reproductive stages in the sheep
}

\author{
G. Jenkin*, R. B. Heap and D. B. A. Symons \\ A.R.C. Institute of Animal Physiology, Babraham, Cambridge CB2 4AT, U.K.
}

\begin{abstract}
Summary. In sheep the basal concentration of LH in jugular vein plasma was significantly higher during the first 50 days of gestation than in late pregnancy or at parturition. The pituitary response to a single i.v. injection of $200 \mu \mathrm{g}$ synthetic LH-RH was determined at different stages of gestation and compared with that of anoestrous and cyclic sheep. Pituitary response to LH-RH decreased progressively with advancing gestation: by 56 days after mating the response had declined to $35 \%$ and by parturition to $14 \%$ of the value in anoestrous sheep. The pituitary response to $\mathrm{LH}-\mathrm{RH}$ increased after parturition and the pattern of recovery differed in non-lactating and lactating sheep. By 63 days post partum the response to $\mathrm{LH}-\mathrm{RH}$ in non-lactating and lactating animals had returned to values similar to those in sheep during anoestrus and sheep during the luteal phase of the oestrous cycle.

A decrease in pituitary responsiveness during pregnancy was associated with a decrease in pituitary content of LH. The quantity of LH released in response to a standard injection of LH-RH was linearly related to pituitary LH content.
\end{abstract}

\section{Introduction}

In sheep the preovulatory surge of LH is stimulated by a positive feedback effect of oestrogen. The infusion or the injection of oestradiol-17 $\beta$ into anoestrous or ovariectomized animals causes a sharp rise in plasma LH after a latent period of about $12 \mathrm{~h}$ (Goding et al., 1969; Pelletier \& Signoret, 1969; Radford, Wheatley \& Wallace, 1969; Scaramuzzi, Tillson, Thorneycroft \& Caldwell, 1971). Pituitary responsiveness, however, is influenced by the levels of ovarian hormones. Treatment with oestradiol$17 \beta$ or LH-RH has a greater effect on LH release at the onset of behavioural oestrus than during the luteal phase (Bolt, Kelly \& Hawk, 1971; Cumming, Brown, Blockey \& Goding, 1971; Foster \& Crighton, 1976). In the present study we have looked for possible changes in pituitary responsiveness to LH-RH during the reproductive cycle and investigated the relationship between responsiveness and the concentration of pituitary LH. A further aim was to examine the influence of lactation on pituitary sensitivity to LH-RH. Preliminary reports of this work have been published previously (Jenkin \& Heap, 1974; Jenkin, 1975).

\section{Materials and Methods}

\section{Animals}

Multiparous Clun Forest or Finnish Landrace ewes were used in all experiments except where stated. The day of oestrus (Day 0) and the time of gestation were determined from daily records of marking by a vasectomized or intact ram fitted with a 'Sire-Sine' harness and crayon. Sheep were brought in from a paddock adjacent to the animal house and placed in individual pens at least $24 \mathrm{~h}$ before an experiment. They were allowed free access to food and water throughout.

* Present address: Nuffield Institute of Medical Research and Department of Obstetrics \& Gynaecology, University of Oxford, John Radcliffe Hospital, Headington, Oxford OX3 9DV, U.K. 
Experiments with LH-RH were repeated on the same animal at intervals of not less than 16 days. Details of the various groups are given in the Tables. Sheep which were not mated during the normal breeding season and were studied during seasonal anoestrus are described as anoestrous. Animals that became pregnant during the normal breeding season and were used for experiments after parturition and during seasonal anoestrus are described as post partum (lactating or non-lactating). Lambs were kept with lactating ewes and not separated from them during the experimental period. Pregnant animals were brought into the animal house at least 4 days before the expected date of parturition and remained indoors until 2 weeks post partum.

\section{Plasma LH}

The concentration of LH was measured in peripheral plasma to determine the basal value at various reproductive stages to compare results in anoestrous and cyclic ewes with those in pregnant, parturient and post-partum animals. Particular attention was given to animals near term to determine the effect of a sharp rise in plasma unconjugated oestrogen level which occurs during the last $48 \mathrm{~h}$ of gestation. The post-partum ewes were allocated to groups according to whether they were lactating (with lambs) or not lactating (lambs removed at birth). Blood samples were taken by jugular venepuncture. All samples were centrifuged within $15 \mathrm{~min}$ of collection and plasma was stored at $-15^{\circ} \mathrm{C}$.

\section{Treatment with $\mathrm{LH}-\mathrm{RH}$ and blood sampling}

Sheep were given $200 \mu \mathrm{g}$ of the synthetic decapeptide, LH-RH (Hoechst Pharmaceuticals), through a polyvinyl catheter (Portex NT3, SH90, $1.4 \mathrm{~mm}$ i.d., $2.0 \mathrm{~mm}$ o.d.) inserted on the day before an experiment $10 \mathrm{~cm}$ into a jugular vein by the method of Seldinger (1953). In preliminary experiments a dose of $200 \mu \mathrm{g} \mathrm{LH}-\mathrm{RH}$ was found to produce a maximum plasma LH concentration in anoestrous ewes similar to that found at oestrus. Blood samples $(2.5 \mathrm{ml})$ were taken from the same catheter into heparinized plastic syringes every $10-15 \mathrm{~min}$ for $30 \mathrm{~min}$ before and $120 \mathrm{~min}$ after injection, and every 20-30 min for a further $200 \mathrm{~min}$.

\section{Pituitary responsiveness to $L H-R H$}

The responsiveness of the pituitary to LH-RH was assessed by measuring the maximum plasma concentration of LH after LH-RH injection (maximum peak height), the time taken to reach this value (time to maximum peak height), and the area under the curve of LH release from 0-320 min (area under curve) calculated by the trapezoidal rule (Abramowitz \& Stegun, 1968). Plasma LH values returned to preinjection levels within $320 \mathrm{~min}$ after injection so that the area, expressed in ( $\mathrm{ng} / \mathrm{ml}$ ) $\tau$, was proportional to the total amount of $\mathrm{LH}$ released ( $\tau$ represents the period of the experiment from 0-320 min). The injection of $250 \mu \mathrm{g} \mathrm{TRH}$ in $2 \mathrm{ml}$ saline or of $2 \mathrm{ml}$ saline alone as control procedures did not increase LH concentration in peripheral plasma.

\section{Pituitary content of $\mathrm{LH}$}

Sheep were anaesthetized with halothane (Fluothane: I.C.I. Pharmaceuticals) and exsanguinated. The anterior pituitary was removed, weighed and immediately frozen in liquid nitrogen and stored at $-15^{\circ} \mathrm{C}$. Before assay, the pituitary was thawed at $4^{\circ} \mathrm{C}$, homogenized in $8 \mathrm{ml}$ cold $0 \cdot 1 \mathrm{M}$-ammonium sulphate, pH 5.5 (Dick \& Gay, 1969), using a polytetrafluoroethylene mortar, and centrifuged at $4^{\circ} \mathrm{C}$ for $30 \mathrm{~min}$ at $17,000 \mathrm{~g}$. The supernatant was removed and assayed for LH and results obtained from at least two dilutions were used in subsequent calculations. The results were linear over the range of dilutions used ( 1 in 25 to 1 in $1000, y=13.74-0.02 x, r=0.66, P<0.05, n=12$ ). Storage of supernatants for up to 1 year at $-15^{\circ} \mathrm{C}$ did not affect the quantity of immunoreactive LH present. 


\section{Radioimmunoassay of $\mathrm{LH}$}

The radioimmunoassay was similar to the solid-phase method described by Goding et al. (1969).

The antiserum ( $\mathrm{LH} \mathrm{3/5)} \mathrm{was} \mathrm{raised} \mathrm{in} \mathrm{adult} \mathrm{New} \mathrm{Zealand} \mathrm{White} \mathrm{rabbits} \mathrm{injected} \mathrm{with} 2 \mathrm{mg}$ NIH-LH-S16 emulsified in Freunds complete adjuvant at 0 and 21 days (i.m.) and 77 days (s.c.) and was obtained 79 days after the first injection. It was stored at $-15^{\circ} \mathrm{C}$ as a 1 in 100 solution in $0.05 \mathrm{M}$ carbonate buffer, $\mathrm{pH} 9 \cdot 2$, and further diluted to a titre of 1 in 10,000 before use.

Purified ovine LH (LER-1056-C2) was iodinated by the chloramine-T method of Greenwood, Hunter \& Glover (1963) using a remotely operated system (Henville \& Jenkin, 1973). Iodinated LH was separated from free iodine on a column of Sephadex G25 fine, $5 \times 1 \mathrm{~cm}$. The ${ }^{125} \mathrm{I}$-labelled LH fraction was added to a column of Whatman CF11 cellulose, $2 \times 0.5 \mathrm{~cm}$, washed with $20 \mathrm{ml} 0.05 \mathrm{M}$ phosphate buffer, $\mathrm{pH} 7 \cdot 5$, to remove unreacted ${ }^{125} \mathrm{I}$ and damaged or fragmented ${ }^{125} \mathrm{I}$-labelled LH (Hunter, Willoughby \& Strong, 1968), and undamaged LH was eluted with $0.05 \mathrm{M}$-phosphate buffer containing $5 \%(\mathrm{w} / \mathrm{v})$ bovine serum albumin. ${ }^{125} \mathrm{I}$-labelled $\mathrm{LH}$ was stored at $4^{\circ} \mathrm{C}$ for up to 3 weeks without loss of immunoreactivity. In each assay ${ }^{125}$ I-labelled LH was diluted to $6.0 \times 10^{4} \mathrm{~d} / \mathrm{min} /$ $0.1 \mathrm{ml}$ with $0.01 \mathrm{M}$-phosphate buffer containing $0.15 \% \mathrm{NaCl}, 0.1 \%$ bovine serum albumin and $0.01 \%$ merthiolate, $\mathrm{pH} \mathrm{7.4} \mathrm{(Buffer} \mathrm{A).} \mathrm{NIH-LH-S17} \mathrm{was} \mathrm{dissolved} \mathrm{in} \mathrm{Buffer} \mathrm{A} \mathrm{to} \mathrm{provide} \mathrm{assay} \mathrm{standards}$ over the range $0.097-50 \mathrm{ng} / 0.8 \mathrm{ml}$. Results were expressed in terms of NIH-LH-S17 which has a biological potency of 1.01 NIH-LH-S1.

Assays were carried out in polystyrene tubes (Luckham LP3) prepared by filling with $1 \mathrm{ml} \mathrm{LH}$ antiserum at 1 in 10,000 dilution. After standing overnight in a saturated atmosphere at room temperature, the antiserum was removed by aspiration and stored at $4^{\circ} \mathrm{C}$ for further use. Tubes were washed twice with $0.9 \% \mathrm{NaCl}$ and once with Buffer $\mathrm{A}$. Coated tubes could be stored at $4{ }^{\circ} \mathrm{C}$ for several weeks before assay.

Plasma samples $(0.2 \mathrm{ml}$ and $0.8 \mathrm{ml}$ Buffer $\mathrm{A})$ and standards $(0.8 \mathrm{ml}$ and $0.2 \mathrm{ml}$ plasma from a hypophysectomized goat) were added to assay tubes and, after mixing, were incubated for $8 \mathrm{~h}$ at room temperature in a humid atmosphere. Pituitary extracts were diluted and assayed in Buffer A alone. Approximately $6.0 \times 10^{4} \mathrm{~d} / \mathrm{min}^{125} \mathrm{I}$-labelled $\mathrm{LH}$ was added in $0.1 \mathrm{ml}$ Buffer A and the tubes incubated for a further $18-24 \mathrm{~h}$ at $4^{\circ} \mathrm{C}$. The contents were then aspirated, the tubes washed twice with tap water, and the bound radioactivity measured. The calibration curve was fitted by computer to an asymptotic decay curve (Walters, 1974) and the sample concentration calculated as the mean of duplicates or triplicates ( $\mathrm{ng} / \mathrm{ml}$ ) by interpolation (Broad, Challis, Heap, Jenkin \& Walters, 1972).

The antiserum showed no significant cross-reaction with NIH-FSH-S8, NIH-GH-S10 or NIH-PS7 over the range of 0.1 to $250 \mathrm{ng} / \mathrm{ml}$. TSH showed an apparent cross-reaction of $10 \%$ at $50 \%$ binding of $\mathrm{I}^{125}$-labelled $\mathrm{LH}$ which was due to contamination of the TSH preparation with immunoreactive LH (Jenkin, 1975). The measurement of known amounts of NIH-LH-S17 added to Buffer A or to plasma from a hypophysectomized goat plotted against the amount added gave regression lines that were highly significant $(y=1.20 x, r=0.998, P<0.001, n=39$; and $y=1.01 x, r=0.957, P<0.001$, $n=46$, respectively). The lowest concentration of $\mathrm{LH}$ distinguishable from zero was $0.75 \pm 0.20$ (S.E.M.) $\mathrm{ng} / \mathrm{ml}$. The determination of a standard amount of LH in buffer $(7 \cdot 1 \mathrm{ng} / \mathrm{ml})$ or plasma $(5 \cdot 1$ $\mathrm{ng} / \mathrm{ml}$ ) gave a standard deviation of $\pm 0.8 \mathrm{ng} / \mathrm{ml}$ ( 5 assays) and $\pm 1.5 \mathrm{ng} / \mathrm{ml}$ (31 assays) respectively.

\section{Results}

\section{Plasma $L H$ concentrations}

These are shown in Table 1 for sheep at various stages of the reproductive cycle. The concentrations during seasonal anoestrus and in the luteal phase of the oestrous cycle were low. During gestation the plasma LH concentration was highest in the first 7 weeks, and was significantly lower between 16 and 21 weeks, and was even lower by the time of parturition. Within 7 weeks after parturition plasma $\mathrm{LH}$ values were significantly higher than those at term and were similar to those in early pregnancy. There was no significant difference in lactating or non-lactating anoestrous sheep at different times after parturition. 
Table 1. Mean \pm S.E.M. plasma LH concentrations in the jugular vein of sheep

\begin{tabular}{|c|c|c|c|c|c|c|}
\hline $\begin{array}{l}\text { Reproductive } \\
\text { state of ewe }\end{array}$ & Group & $\begin{array}{l}\text { Time of sampling } \\
\text { (weeks post coitum) }\end{array}$ & $\begin{array}{l}\text { No. of } \\
\text { samples }\end{array}$ & $\begin{array}{l}\text { No. of } \\
\text { animals }\end{array}$ & $\begin{array}{l}\text { LH conc. } \\
(\mathrm{ng} / \mathrm{ml})\end{array}$ & $\begin{array}{l}\text { Statistical } \\
\text { significancet }\end{array}$ \\
\hline Anoestrous & $\mathbf{A}$ & $\begin{array}{l}\text { Anoestrous period } \\
\text { (April-August) }\end{array}$ & 27 & 11 & $1 \cdot 8 \pm 0.4$ & $\begin{array}{l}>\mathrm{F} * * * \\
>\mathrm{B},>\mathrm{E} *\end{array}$ \\
\hline Cyclic & $\mathbf{B}$ & $\begin{array}{l}\text { Days } 5-13 \text { of } \\
\text { oestrous cycle }\end{array}$ & 46 & 15 & $1.0 \pm 0.2$ & $<A,<C_{*}$ \\
\hline Pregnant & $\begin{array}{l}\text { C \& D } \\
\text { E } \\
\text { F }\end{array}$ & $\begin{array}{l}2-7 \\
10-16 \\
16-20\end{array}$ & $\begin{array}{l}23 \\
23 \\
99\end{array}$ & $\begin{array}{r}4 \\
4 \\
15\end{array}$ & $\begin{array}{l}1.7 \pm 0.4 \\
1.2 \pm 0.3 \\
1.0 \pm 0.1\end{array}$ & $\begin{aligned}>\mathrm{F} * * * \\
>\mathrm{B},>\mathrm{E} * \\
\quad \mathrm{~N} . \mathrm{S} . \\
<\mathrm{A} * * \\
<\mathrm{C} *\end{aligned}$ \\
\hline Parturient & $G$ & $\begin{array}{c}20-21 \\
\text { (near term) } \ddagger\end{array}$ & 62 & 15 & $0.7 \pm 0.1$ & $\begin{array}{l}<\mathrm{A},<\mathrm{C},<\mathrm{I} * * * \\
<\mathrm{J} * *\end{array}$ \\
\hline $\begin{array}{r}\text { Post partum } \\
\text { (lactating) }\end{array}$ & $\begin{array}{l}\mathbf{H} \\
\mathbf{I} \\
\mathbf{J} \\
\mathbf{K}\end{array}$ & $\begin{array}{l}1-2 \\
3-5 \\
5-7 \\
8-10\end{array}$ & $\begin{array}{r}21 \\
8 \\
6 \\
8\end{array}$ & $\begin{array}{r}15 \\
6 \\
6 \\
6\end{array}$ & $\begin{array}{l}0.9 \pm 0.3 \\
0.9 \pm 0.4 \\
1.7 \pm 0.8 \\
1.5 \pm 0.4\end{array}$ & $\begin{array}{c}\text { N.S. } \\
\text { N.S. } \\
>\text { F*** } \\
>\text { F** }\end{array}$ \\
\hline $\begin{array}{l}\text { Post partum } \\
\quad \text { (not lactating) }\end{array}$ & $\begin{array}{l}\mathbf{L} \\
\mathbf{M} \\
\mathbf{N} \\
\mathbf{O}\end{array}$ & $\begin{array}{l}1-2 \\
3-5 \\
5-7 \\
8-10\end{array}$ & $\begin{array}{r}6 \\
11 \\
11 \\
17\end{array}$ & $\begin{array}{l}3 \\
6 \\
6 \\
7\end{array}$ & $\begin{array}{l}0.4 \pm 0.2 \\
0.6 \pm 0.1 \\
1.6 \pm 0.4 \\
1.7 \pm 0.5\end{array}$ & $\left\{\begin{array}{l}\text { Not significantly } \\
\text { different from } \\
\text { Groups } H, I, J \text { or } \mathrm{K}\end{array}\right.$ \\
\hline
\end{tabular}

$* P<0.05 ; * * P<0.01 ; * * * P<0.001$, N.S. $=$ no significant difference $(P>0.05)$.

$\uparrow$ Measured by multifactorial analysis of variance.

$\$ 3$ days before to 3 days after parturition.

Table 2. The release of $\mathrm{LH}$ (mean \pm S.E.M.) after the injection of LH-RH in sheep

\begin{tabular}{|c|c|c|c|c|c|c|}
\hline $\begin{array}{l}\text { Reproductive } \\
\text { state }\end{array}$ & Group & $\begin{array}{l}\text { Time of LH-RH } \\
\text { injections (weeks } \\
\text { post coitum) }\end{array}$ & $\begin{array}{l}\text { No. of } \\
\text { animals }\end{array}$ & $\begin{array}{l}\text { Maximum LH conc. } \\
\text { (ng/ml) }\end{array}$ & $\begin{array}{l}\text { Area under the } \\
\text { curve of } \mathrm{LH} \\
\text { release }(\mathrm{ng} / \mathrm{ml}) \tau\end{array}$ & $\begin{array}{c}\text { Total peak } \\
\text { area as } \% \text { of } \\
\text { anoestrous } \\
\text { value }\end{array}$ \\
\hline Anoestrous & $\mathbf{A}$ & $\begin{array}{l}\text { Anoestrous period } \\
\text { (April-August) }\end{array}$ & 11 & $63 \cdot 2 \pm 7 \cdot 7$ & $8030 \pm 897$ & 100 \\
\hline Cyclic & B & $\begin{array}{l}\text { Days 5-13 of } \\
\text { oestrous cycle }\end{array}$ & 15 & $63 \cdot 8 \pm 12 \cdot 0$ & $6885 \pm 1232$ & $85 \cdot 7$ \\
\hline Pregnant & $\begin{array}{l}\text { C } \\
\text { D } \\
\text { E } \\
\text { F }\end{array}$ & $\begin{array}{c}2-4 \\
6-9 \\
10-13 \\
15-20\end{array}$ & $\begin{array}{l}4 \\
4 \\
6 \\
9\end{array}$ & $\begin{array}{l}49 \cdot 6 \pm 14 \cdot 6 \\
19 \cdot 0 \pm 4 \cdot 2 \\
14 \cdot 1 \pm 2 \cdot 4 \\
14 \cdot 0 \pm 2 \cdot 9\end{array}$ & $\begin{array}{l}5764 \pm 1919 \\
2832 \pm 796 \\
1836 \pm 411 \\
2131 \pm 508\end{array}$ & $\begin{array}{l}71 \cdot 8 \\
35 \cdot 3 \\
22 \cdot 9 \\
26 \cdot 5\end{array}$ \\
\hline Parturient* & G & $20-21$ & 6 & $8 \cdot 8 \pm 1.6$ & $1159 \pm 131$ & $14 \cdot 4$ \\
\hline $\begin{array}{l}\text { Post partum } \\
\text { (lactating) }\end{array}$ & $\begin{array}{l}\mathbf{H} \\
\mathbf{I} \\
\mathbf{J} \\
\mathbf{K}\end{array}$ & $\begin{array}{l}1-2 \\
3-5 \\
5-7 \\
8-10\end{array}$ & $\begin{array}{l}7 \\
7 \\
6 \\
6\end{array}$ & $\begin{array}{l}29.6 \pm 7.5 \\
30.6 \pm 5.2 \\
38.4 \pm 9.4 \\
60.3 \pm 18.3\end{array}$ & $\begin{array}{l}3959 \pm 965 \\
3997 \pm 714 \\
5212 \pm 1130 \\
7488 \pm 1436\end{array}$ & $\begin{array}{l}49 \cdot 3 \\
49 \cdot 8 \\
64 \cdot 9 \\
93 \cdot 3\end{array}$ \\
\hline $\begin{array}{l}\text { Post partum } \\
\quad \text { (not lactating) }\end{array}$ & $\begin{array}{l}\mathrm{L} \\
\mathrm{M} \\
\mathrm{N} \\
\mathrm{O}\end{array}$ & $\begin{array}{l}1-2 \\
3-5 \\
5-7 \\
8-10\end{array}$ & $\begin{array}{l}3 \\
6 \\
7 \\
7\end{array}$ & $\begin{array}{l}30 \cdot 2 \pm 10 \cdot 3 \\
76 \cdot 8 \pm 21 \cdot 2 \\
53 \cdot 7 \pm 4 \cdot 2 \\
61 \cdot 1 \pm 14 \cdot 1\end{array}$ & $\begin{array}{l}4212 \pm 1488 \\
8947 \pm 1087 \\
7939 \pm 559 \\
7383 \pm 1480\end{array}$ & $\begin{array}{r}52.5 \\
111.4 \\
98.9 \\
91.9\end{array}$ \\
\hline
\end{tabular}

* Days 0-5 after parturition. 


\section{Pituitary responsiveness to $L H-R H$}

The responsiveness of the pituitary to LH-RH was determined in 102 experiments on 37 sheep at various times of the reproductive cycle (Table 2). The time from LH-RH injection to the maximum LH value found in plasma (time to maximum peak height) did not differ significantly at any time during the reproductive cycle, the mean value for all groups being $100 \pm 2$ (S.E.M.) min. The magnitude of the response, however, showed a marked change as determined by the highest concentration of $\mathrm{LH}$ observed ( $\mathrm{ng} / \mathrm{ml}$ plasma) or by the area under the curve of LH release. Both estimations were closely correlated $(r=0.96, P<0.001, y=0.0088 x-4.43, n=102)$ and pituitary responsiveness is subsequently described in terms of the latter estimation.

The area under the curve of LH release after LH-RH treatment was high in sheep during anoestrus, in the luteal phase of the oestrous cycle, and during the first 4 weeks of gestation. As pregnancy progressed the pituitary responsiveness to $\mathrm{LH}-\mathrm{RH}$ declined to $23 \%$ of that in anoestrous animals, whereas at parturition it was only $14.4 \%$ of the value at anoestrus.

In contrast to the gradual decrease in pituitary responsiveness during pregnancy, recovery after parturition was rapid. By 14 days post partum pituitary LH release in response to LH-RH in lactating and non-lactating sheep was about half that found in anoestrous animals. Thereafter the pattern of recovery in lactating sheep was different from that in non-lactating animals. By 3-5 weeks after parturition $\mathrm{LH}$ release was $50 \%$ and $111 \%$ in lactating and non-lactating animals, respectively, of the mean value found in anoestrous animals. By 8-10 weeks post partum $\mathrm{LH}$ release was similar to anoestrous values in all post-parturient sheep.

Table 3. Mean \pm S.E.M. pituitary LH concentration and content in sheep at various reproductive stages

\begin{tabular}{|c|c|c|c|c|c|c|}
\hline $\begin{array}{l}\text { Repro- } \\
\text { ductive } \\
\text { state }\end{array}$ & Group & $\begin{array}{c}\text { Time of collection } \\
\text { (weeks } \\
\text { post coitum) }\end{array}$ & $\begin{array}{l}\text { No. of } \\
\text { animals }\end{array}$ & $\begin{array}{l}\text { Pituitary } \\
\text { conc. } \\
(\mu \mathrm{g} / \mathrm{g} \text { tissue })\end{array}$ & $\begin{array}{l}\text { Pituitary } \\
\text { content } \\
(\mu g)\end{array}$ & $\begin{array}{l}\text { Statistical significance } \\
\text { of pituitary conc. }\end{array}$ \\
\hline Anoestrous & A & $\begin{array}{l}\text { Anoestrous period } \\
\text { (April-August) }\end{array}$ & 7 & $1135 \cdot 0 \pm 302 \cdot 3$ & $754 \cdot 5 \pm 150 \cdot 2$ & $>\mathrm{F} *,<\mathrm{C} * *$ \\
\hline$\overline{\text { Cyclic }}$ & $\bar{B}$ & $\begin{array}{l}\text { Days } 5-13 \text { of } \\
\text { oestrous cycle }\end{array}$ & 5 & $1354 \cdot 5 \pm 207 \cdot 5$ & $874 \cdot 0 \pm 121 \cdot 8$ & $\begin{array}{l}<\mathrm{C} * *,>\mathrm{F} * *,>\mathrm{H} * \\
>\mathrm{E} * *,>\mathrm{G} * *\end{array}$ \\
\hline \multirow[t]{4}{*}{ Pregnant } & $\mathrm{C}$ & $2-4$ & $3 \dagger$ & $2890 \cdot 4 \pm 282 \cdot 1 \dagger$ & $735 \pm 45 \cdot 5$ & $\begin{array}{l}>\mathrm{A} * *,>\mathrm{E} * * *,>\mathrm{H} * * *,>\mathrm{K} * * * \\
>\mathrm{B} * *,>\mathrm{F} * * *,>\mathrm{I} * * * \\
>\mathrm{D} * * *,>\mathrm{G} * * *,>\mathrm{J} * * *\end{array}$ \\
\hline & D & $6-9$ & 7 & $872 \cdot 9 \pm 175 \cdot 7$ & $535 \cdot 0 \pm 116 \cdot 6$ & $\begin{array}{l}<\mathrm{C} * * *,>\mathrm{G} * \\
>\mathrm{F} *\end{array}$ \\
\hline & $\mathbf{E}$ & $10-16$ & 8 & $505 \cdot 7 \pm 107 \cdot 5$ & $304 \cdot 0 \pm 64 \cdot 9$ & $\begin{array}{l}<\mathrm{B} * *,<\mathrm{J} * \\
<\mathrm{C} * * *\end{array}$ \\
\hline & $\mathbf{F}$ & $16-20$ & 6 & $174 \cdot 8 \pm 125 \cdot 7$ & $183 \cdot 1 \pm 64 \cdot 9$ & $\begin{array}{l}<\mathrm{A} *,<\mathrm{D} *,<\mathrm{J} * * \\
<\mathrm{B} * *,<\mathrm{I} *,<\mathrm{K} * \\
<\mathrm{C} * * *\end{array}$ \\
\hline Parturient & G & $20-21$ & 3 & $120 \cdot 8 \pm 56 \cdot 0$ & $111 \cdot 8 \pm 17 \cdot 7$ & $\begin{array}{l}<\mathrm{B} * *,<\mathrm{D} *,<\mathrm{J} * \\
<\mathrm{C} * * *,<\mathrm{I} * *,<\mathrm{K} * *\end{array}$ \\
\hline \multirow[t]{4}{*}{$\begin{array}{l}\text { Post partum } \\
\quad \text { (lactating) }\end{array}$} & $\mathbf{H}$ & $1-2$ & 4 & $511 \cdot 5 \pm 145 \cdot 4$ & $441 \cdot 1 \pm 187 \cdot 5$ & $\begin{array}{l}<\mathrm{B} * \\
<\mathrm{C} * * *\end{array}$ \\
\hline & I & $3-5$ & 4 & $819 \cdot 2 \pm 117 \cdot 1$ & $713 \cdot 6 \pm 147 \cdot 7$ & $\begin{array}{l}<\mathrm{C} * * *,>\mathrm{G} * * \\
>\mathrm{F} *\end{array}$ \\
\hline & $\mathbf{J}$ & $5-7$ & 4 & $1127 \cdot 0 \pm 217 \cdot 7$ & $814 \cdot 9 \pm 147 \cdot 0$ & $\begin{array}{l}<\mathrm{C} * * *,>\mathrm{F} * * \\
>\mathrm{E} *,>\mathrm{G} *\end{array}$ \\
\hline & $\mathbf{K}$ & $8-10$ & 3 & $846 \cdot 1 \pm 89 \cdot 4$ & $1017 \cdot 2 \pm 53 \cdot 5$ & N.S. \\
\hline $\begin{array}{l}\text { Post partum } \\
\text { (not } \\
\text { lactating) }\end{array}$ & $\begin{array}{l}\mathrm{M} \\
\mathrm{N} \\
\mathrm{O}\end{array}$ & $\begin{array}{l}3-5 \\
5-7 \\
8-10\end{array}$ & $\begin{array}{l}4 \\
4 \\
4\end{array}$ & $\begin{array}{c}1082 \cdot 8 \pm 57 \cdot 5 \\
995 \cdot 0 \pm 45 \cdot 8 \\
1041 \cdot 0 \pm 199 \cdot 7\end{array}$ & $\begin{array}{l}843 \cdot 0 \pm 172 \cdot 5 \\
987 \cdot 0 \pm 126 \cdot 1 \\
909 \cdot 2 \pm 162 \cdot 6\end{array}$ & $\left\{\begin{array}{l}\text { Not significantly different } \\
\text { from Groups } \mathrm{H}, \mathrm{I}, \mathrm{J} \text { or } \mathrm{K}\end{array}\right.$ \\
\hline
\end{tabular}

Student's $t$ test, $* P<0.05 ; * * P<0.01 ; * * * P<0.001 ;$ N.S. $=$ no significant difference $(P>0.05)$.

$\uparrow$ Pituitaries from sheep in their first pregnancy; all other animals were multiparous.

$\ddagger$ Day of parturition. 


\section{Pituitary concentration and content of $L H$}

The concentration of LH in the anterior pituitary was high in anoestrous, cyclic and early pregnant sheep (Table 3). There was a linear correlation between the mean value of pituitary content of LH and the mean area under the curve of LH in response to LH-RH (Text-fig. $1 ; r=0.898 ; P<0.001$ ). The slope of the linear regression was 7.967, and the intercept was not significantly different from zero.

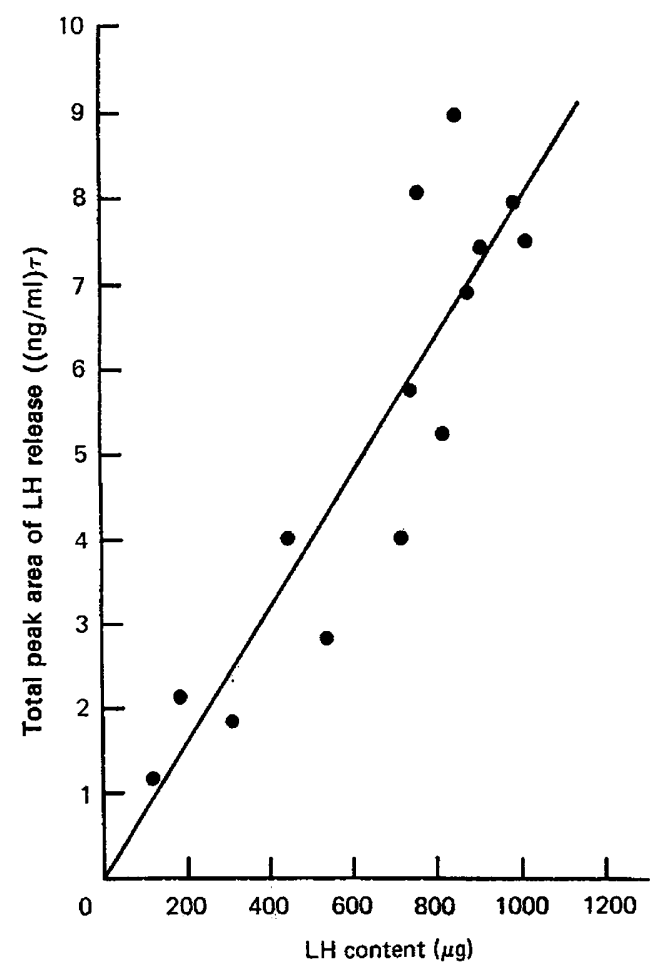

Text-fig. 1. Linear regression of pituitary $\mathbf{L H}$ content and $\mathrm{LH}$ released (area under the curve) during a $320 \mathrm{~min}$ period after a single i.v. injection of $200 \mu \mathrm{g} \mathrm{LH}-\mathrm{RH}$ in sheep. The pituitary content of LH was measured at various times during the reproductive cycle and the mean values are given in Table 3 ; the mean values of pituitary response to LH-RH are given in Table 2.

\section{Discussion}

Pituitary responsiveness to a standard intravenous injection of synthetic LH-RH decreased progressively throughout gestation in sheep and by parturition it was only about $14 \%$ of that in anoestrous animals. These findings confirm and extend those of other workers (Chamley, Findlay, Cumming, Buckmaster \& Goding, 1974a; Chamley, Findlay, Jonas, Cumming \& Goding, 1974b). There was a parallel reduction of pituitary $\mathrm{LH}$ content which was probably related to the high plasma progesterone concentration (Jenkin \& Heap, 1974). The decrease in response to LH-RH observed during pregnancy was not related to daylength since non-pregnant sheep which were in seasonal anoestrus and treated at the same time of year showed a high response to LH-RH (see Table 2). It is also unlikely that the decreased pituitary response observed could be an artefact resulting from an increased systemic clearance of the decapeptide during pregnancy because a similar pattern of decreasing responsiveness was noted when the decapeptide was injected directly into a lateral ventricle of the brain (G. Jenkin \& K. Johnson, unpublished observations), or infused into a carotid artery (Chamley et al., 1974a) in conscious animals. 
Pituitary responsiveness in anoestrous sheep may be enhanced by LH-RH itself (auto-sensitization) since the amount of $\mathrm{LH}$ released after a single injection of the synthetic decapeptide is less than when it is injected repeatedly at 90 -min intervals (Crighton, Foster, Haresign \& Scott, 1975) or infused continuously for $8 \mathrm{~h}$ (Symons, Cunningham \& Saba, 1974). In contrast, a single injection of LH-RH results in an acute loss of responsiveness which lasts for 24-28 h (Rippel, Johnson \& White, 1974). This acute effect does not result from a depletion of pituitary LH stores which remain high even after repeated LH-RH injections. The chronic decrease in pituitary responsiveness found in gestation seems to represent a different phenomenon in which the mean pituitary response is directly related to the mean pituitary content of LH. If the LH released is derived entirely from pituitary stores, the gradual decrease in response during pregnancy may be due simply to a decreased content. If the $\mathrm{LH}$ released after an LH-RH injection were wholly or in part synthesized de novo, then the pituitary content would reflect the synthetic capacity at that time.

A question that arises from these findings is whether LH-RH also regulates the synthesis of pituitary LH in sheep, and whether the decline in pituitary LH content in gestation is associated with a chronic decrease in the sensitivity of the pituitary cells to LH-RH or in the production of LH-RH by the hypothalamus. The decrease in pituitary responsiveness we have observed may be due to a depletion of LH-RH receptors in the pituitary. A depletion of receptors may arise from a decrease in the gonadotroph population of the anterior pituitary which is known to occur during pregnancy in some species (Cameron, Foster \& Allanson, 1966; Allanson, Cameron \& Foster, 1966). In sheep, however, alterations in the gonadotroph population have not so far been conclusively demonstrated (Warbritton \& McKenzie, 1937). If chronic desensitization to LH-RH is related to changes in the number of gonadotrophs it is to be noted that their replenishment after parturition is much more rapid than their depletion during gestation.

The sharp rise in oestrogen secretion which occurs during the last $48 \mathrm{~h}$ of gestation fails to elicit LH release at parturition in contrast to the positive feedback effect of oestradiol-17 $\beta$ during the normal oestrous cycle. This lack of LH release presumably derives from the depletion of pituitary LH content and would explain why ovulation rarely, if ever, occurs in the sheep immediately post partum. In women, a temporary decrease in pituitary response to LH-RH post partum has also been reported (LeMaire, Shapiro, Riggall \& Yang, 1974), probably arising from the negative feedback effect of pregnancy hormones, as in sheep.

We thank Dr J. S. Perry and Dr K. Brown-Grant for helpful discussion of the manuscript; the Meat and Livestock Commission, Milton Keynes, U.K. and the Lalor Foundation, Delaware, U.S.A. for financial support (G.J.); Dr R. W. Bates, NIH, Bethesda, for gifts of ovine pituitary hormones; Professor L. E. Reichert, Jr for purified ovine LH(LER-1056-C2); Mr J. M. J. Best, Hoechst Pharmaceuticals, Hounslow, U.K. for LH-RH; and Dr I. C. Hart and Dr H. L. Buttle, N.I.R.D. Reading, for hypophysectomized goat plasma.

\section{References}

Abramowitz, M. \& Stegun, I.A. (1968) Handbook of Mathematical Functions, p. 885. Dover Publications, Inc. New York.

Allanson, M., Cameron, E. \& Foster, C.L. (1966) Observations on the acidophil cells of the adenohypophysis in pregnant and lactating rabbits. $J$. Reprod. Fert. 12, 319-326.

Bolt, D.J., Kelly, H.E. \& Hawk, H.W. (1971) Release of $\mathrm{LH}$ by estradiol in cycling ewes. Biol. Reprod. 4, $35-40$.

Broad, S., Challis, J.R.G., Heap, R.B., Jenkin, G. \& Walters, D.E. (1972) Computer analysis of multiple hormone assays (cortisol, oestrogens, progesterone and LH). J. Physiol., Lond. 226, 23-24P.
Cameron, E., Foster, C.L. \& Allanson, M. (1966) The mucoid cells of the adenohypophysis of the rabbit during pregnancy and lactation. $J$. Reprod. Fert. 12, 199-302.

Chamley, W.A., Findlay, J.K., Cumming, I.A., BUCKMASTER, J.M. \& GoDING, J.R. (1974a) Effect of pregnancy of the LH response to synthetic gonadotrophin-releasing hormone in the ewe. Endocrinology 94, 291-293.

Chamley, W.A., Findlay, J.K., Jonas, H., Cumming, I.A. \& GoDING, J.R. (1974b) Effect of pregnancy on the FSH response to synthetic gonadotrophinreleasing hormone in ewes. $J$. Reprod. Fert. 37, 109112. 
Crighton, D.B., Foster, J.P., Haresign, W. \& Scott, S.A. (1975) Plasma LH and progesterone levels after single or multiple injections of synthetic LH-RH in anoestrous ewes and comparison with levels during the oestrous cycle. J. Reprod. Fert. 44, 121-124.

Cumming, I.A., Brown, J.M., Blockey, M.A. DE B. \& GoDING, J.R. (1971) Regulation of the oestrous cycle of the ewe. J. Reprod. Fert. 24, 148-149.

Dick, C.R. \& GAY, V.L. (1969) Extractability of rat pituitary $\mathrm{LH}$ as judged by radioimmunoassay. Fedn Proc. Fedn Am. Socs exp. Biol. 28, 505.

Foster, J.P. \& CRIGHTON, D.B. (1976) Luteinizing hormone release after injection of synthetic luteinizing hormone releasing hormone at various stages of the oestrous cycle in the sheep. $J$. Endocr. 68, 41-42P.

Goding, J.R., CatT, K.J., Brown, J.M., Kaltenbach, C.C., Cumming, I.A. \& Mole, B.J. (1969) Radioimmunoassay for ovine luteinizing hormone. Secretion of luteinizing hormone during estrus and following estrogen administration in the sheep. Endocrinology 85, 133-142.

Greenwood, F.C., Hunter, W.M. \& Glover, J.S. (1963) The preparation of ${ }^{131}$ I-labelled human growth hormone of high specific radioactivity. Biochem. $J$. 89, 114-123.

Henville, A. \& Jenkin, G. (1973) A simple and cheap remotely operated system for the iodination of proteins. Analyt. Biochem. 52, 336-341.

Hunter, W.M., Willoughby, J.M.T. \& Strong, J.A. (1968) Plasma insulin and growth hormone during 22 hour fasts and after graded glucose loads in six healthy adults. J. Endocr. 40, 297-311.

Jenkin, G. (1975) Pituitary function in the sheep, factors affecting the synthesis and release of luteinizing hormone. Ph.D. thesis, University of Cambridge.

Jenkin, G. \& Heap, R.B. (1974) The lack of response of the sheep pituitary to luteinizing hormone releasing hormone stimulation in gestation and early lactation; the probable role of progesterone.J. Endocr. 61, xii-xiii.

LeMaire, W.J., Shapiro, A.G., Riggall, F. \& Yang, N.S.T. (1974) Temporary pituitary insensitivity to stimulation by synthetic LRH during postpartum period. J. clin. Endocr. Metab. 38, 916-918.

Pelletier, J. \& Signoret, J.P. (1969) Contrôle de la décharge de $\mathrm{LH}$ dans le sang par la progestérone et le benzoate d'oestradiol chez la brebis castrée. $C$. $r$. hebd. Séanc. Acad. Sci., Paris 269, 2595-2598.

RADFord, H.M., Wheatley, I.S. \& Wallace, A.L.C. (1969) The effect of oestradiol benzoate and progesterone on secretion of luteinizing hormone in the ovariectomized ewe. J. Endocr. 44, 135-136.

RipPel, R.H., JohNSON, E.S. \& WHITE, W.F. (1974) Effect of consecutive injections of synthetic gonadotrophin RH on LH release in the anestrous and ovariectomized ewe. J. Anim. Sci. 39, 907-914.

Scaramuzzi, R.J., Tillson, S.A., Thorneycroft, I.H. \& Caldwell, B.V. (1971) Action of exogenous progesterone and estrogen on behavioural estrus and luteinizing hormone levels in the ovariectomized ewe. Endocrinology 88, 1184-1189.

SELDINGER, S.I. (1953) Catheter replacement of the needle in percutaneous arteriography. A new technique. Acta radiol. 39, 368-376.

Symons, A.M., Cunningham, N.F. \& Saba, N. (1974) The gonadotrophic hormone response of anoestrous and cyclic ewes to synthetic luteinizing hormonereleasing hormone. J. Reprod. Fert. 39, 11-21.

WALTERS, D.E. (1974) The use of asymptotic models in multiple hormone assays. Appl. Statist. 23, 4350.

WARBRITTON, V. \& McKenzIE, F.F. (1937) The pituitary glands of ewes in various phases of reproduction. Res. Bull. Univ. Mo. Agric. exp. Stn 257, 2-59.

Received 16 June 1976 